\title{
Analisis Kemampuan Pemecahan Masalah Matematis : Dampak Model Pembelajaran Superitem Berbantuan Scaffholding
}

\author{
Ahmad Kausar Jaya ${ }^{*}$, Sofyan M Soleh ${ }^{1}$, Heny Wulandari ${ }^{1}$ \\ Universitas Islam Negeri Raden Intan Lampung. Jalan Endro Suratmin, Sukarame, Bandar \\ Lampung35133, Indonesia \\ *Corresponding Author. E-mail: kausarr559@gmail.com
}

Received : 13-08-2018; Revised : 19-09-2018; Accepted : 30-09-2018

\begin{abstract}
Abstrak
Penelitian ini bertujuan untuk mengetahui pengaruh penggunaan model superitem berbantuan scaffolding terhadap kemampuan pemecahan masalah matematis peserta didik. Teknik pengambilan sample yang digunakan adalah cluster random sampling dengan 3 kelas yaitu kelas eksperimen 1 (kelas mendapat perlakuan model pembelajaran superitem berbantuan scaffolding), kelas eksperimen 2 (pembelajaran superitem saja) serta kelas kontrol (kelas mendapat perlakuan model konvensional). Uji hipotesis yang digunakan adalah anava 1 jalan sel tak sama. Hasil penelitian memperoleh bahwa ada perbedaan kemampuan pemecahan maslah matematis pesertaa didik dengan menggunakan model pemebelajaran superiten berbantuan scaffolding. Selanjutnya kemampuan pemecahan masalah matematis peserta didik dengan model pembelajaran superitem berbantuan scaffholding sama dengan kemampuan pemecahan masalah matematis peserta didik menggunakan model pembelajaran superitem. Kemampuan pemecahan masalah matematis peserta didik dengan model pembelajaran superitem berbantuan scaffholding lebih baik dari pada kemampuan pemecahan masalah matematis peserta didik menggunakan model pembelajaran konvensional. Selanjutnya kemampuan pemecahan masalah matematis peserta didik dengan model pembelajaran superitem sama dengan kemampuan pemecahan masalah matematis peserta didik menggunakan model pembelajaran konvensional.
\end{abstract}

Kata kunci : pemecahan masalah matematis, Scaffholding, Superitem.

\begin{abstract}
This study aims to determine the effect of the use of the super-scaled model of scaffolding on students' mathematical problem solving abilities. The sampling technique used was cluster random sampling with 3 classes namely experimental class 1 (the class was treated with scaffolding assisted superememe learning model), experimental class 2 (superitem learning only) and control class (the conventional treatment class). Hypothesis testing used is anava 1 cell path is not the same. The results of the study found that there were differences in students' mathematical problem solving abilities by using learning models of scaffolding assisted supermarkets. Furthermore, the mathematical problem solving ability of students with the super-intensive learning model assisted by scaffholding is the same as the mathematical problem-solving ability of students using superemit learning models. The mathematical problem solving ability of students with superficial learning models assisted by scaffholding is better than the students' mathematical problem-solving abilities using conventional learning models. Furthermore, the mathematical problem solving ability of students with superemit learning models is the same as the mathematical problem solving ability of students using conventional learning models.
\end{abstract}

Key words: creative thinking ability, scaffholding, superitem. 


\section{PENDAHULUAN}

Pemecahan masalah
merupakan salah satu tipe
keterampilan intelektual yang
menurut (Novianti, 2017) lebih tinggi
derajatnya dan lebih kompleks dari
tipe keterampilan intelektual lainnya. (Qamar \& Riyadi, 2016) berpendapat bahwa dalam menyelesaikan pemecahan masalah diperlukan aturan kompleks atau aturan tingkat tinggi dan aturan tingkat tinggi dapat dicapai setelah menguasai aturan dan konsep terdefinisi. Demikian pula aturan dan konsep terdefinisi dapat dikuasai jika ditunjang oleh pemahaman konsep konkrit. Setelah itu untuk memahami konsep konkrit diperlukan keterampilan dalam memperbedakan (Yuliana, Rokhmat, \& Gunada, 2017). Akan tetapi beberapa dari peserta didik cenderung pasif dalam proses pembelajaran dan kurang kreatif dalam menyelesaikan soal-soal yang diberikan oleh guru. Sehingga kemampuan pemecahan masal matematis peserta didik belum berkembang. Hasil ini didukung oleh hasil data nilai siswa berdasarkan data nilai UTS kelas VII SMP Negeri 1 Teluk Pandan tahun ajaran 2017/2018 semester genap masih dibawah rata-rata. Proses pembelajaran belum menunjukan hasil yang memuaskan karena lebih dari sebagian peserta didik masih mendapatkan nilai di bawah Kriteria Ketuntasan Minimal (KKM), yaitu 75. Beberepa penelitian mengungkapkan bahwa rendahnya kemampuan pemecahan masalah matematis peserta didik karena penggunaan metode pembelajaran yang kurang tepat diguanakan dalam pembelajaran matematika (Amiluddin \& Sugiman, 2016; Dewi, Riastini, \& Pudjawan, 2017; Wulandari, Mujib, \& Putra, 2016) Salah satu alternative pembelajaran yang mungkin dapat meningkatkan pemecahan masalah matematis yaitu dengan pembelajaran superitem. Menurut (Rahman Saleh, 2016) pembelajaran superitem mampu meningkat kemampuan pemecahan masalah matematis peserta didik. Selain itu, (Permatasari, 2014) mengungkapkan bahwa model pembelajaran superitem mampu meningkatkan kemampuan pemahaman matematika peserta didik. Menurut (ASTIWI, 2010) pembelajaran superitem mampu mengembangkan kreatifitas dan kemampuan matematika peserta didik. Suyatno dalam (Pratiwi, Sukestiyarno, \& Asikin, 2014) menjelaskan bahwa metode pembelajaran Superitem merupakan metode pembelajaran dengan cara memberikan tugas kepada siswa secara bertingkat dari yang sederhana hingga kompleks, berupa pemecahan masalah. Atas dasar beberapa rujukan dari penelitian tersebut makan penulis tertarik melakukan penelitian untuki mengatasi kemampuan pemecahan masalah peserta didik dengan menggunakan model superitem.

Agar pembelajaran menggunakan model superitem bisa berjalan lebih optimal masa perkembangannya, maka peserta didik harus diberi bimbingan tahap demi tahap. Merujuk hal ini penulis akan menggunakan sebuah bantuan teori belajar yang tepat yaitu menggunakan scaffolding. Menurut 
Vygotsky yang dikutip dari berberapa penelitian, scaffolding merupakan daerah antar tingkat perkembangan yang sesungguhnya yang didefenisikan sebagai kemampuan pemecahan masalah di bawah bimbingan orang dewasa atau teman sebaya yang lebih mampu (Chairani, 2015; Pratiwi et al., 2014; Sutarmi, Suharsono, \& Warpala, 2013). Sehingga pembelajaran dengan menggunakan model superitem akan lebih optimal jika dilakukan dengan bantuan scaffolding dalam meningkatkan kemampuan pemecahan masalah matematis peserta didik. Seperti yang dijelaskan oleh (Pratiwi et al., 2014) dalam penelitian yang mengungkapkan bahwa pembelajaran matematika menggunakan model superitem akan lebih teroganisir dengan menggukan bantuan scaffolding, karena peserta didik harus dibimbing oleh orangorang dewasa. Sehingga penulis melakukan sebuah penelitian untuk melihat pengaruh model pembelajaran superitem berbantuan scaffolding terhadap kemampuan pemecahan masalah matematis.

Penelitian dengan menggunakan model superimen ini pernah dilakukan oleh penelitian sebelumnya oleh (Permatasari, 2014) namun penelitian ini dilakuan untuk meningkatkan kemampuan pemahaman konsep peserta didik. Keterbaharuan yang dilakukan oleh penulis adalah penulis melihat pengaruh model pembelajaran superitem terhadap kemampuan pemecahan masalah matematis perserta didik. Selain itu oleh (Rahman Saleh, 2016) namun penelitian ini dilakukan dengan bantuan maple. Keterbaharuan penelitian oleh penulis adalah menggunakan bantuan scaffolding. Penelitian oleh (Pratiwi et al., 2014), penilitian ini dilakukan dalam pembeelajaran fisika. Keterbaharuan penelitia penulis adalah pembelajaran model superitem ini dilakukan dalam pembelajaran matematika.

\section{METODE}

Metode penelitian yang digunakan pada penelitian ini adalah menggunakan penelitian eksperimen karena penulis akan mencari perbedaan treatment (perlakuan) tertentu. Desain penelitian yang akan digunakan adalah Posttest-Pretest Control Group Design.

Tabel 2. Rancangan Penelitian Eksperimental

\begin{tabular}{lcc}
\hline Kelas & Perlakuan & Tes Akhir \\
Kelas Eksperimen & $\mathrm{X}_{1}$ & $\mathrm{~T}_{2}$ \\
Kelas Eksperimen & $\mathrm{X}_{2}$ & $\mathrm{~T}_{2}$ \\
Kelas Kontrol & $\mathrm{X}_{3}$ & $\mathrm{~T}_{2}$ \\
\hline
\end{tabular}

keterangan:

$\mathrm{X}_{1}=$ Perlakuan dengan menggunakan model pembelajaran Superitem dan berbantu Scaffolding .

$\mathrm{X}_{2}=$ Perlakuan dengan menggunakan model pembelajaran Superitem.

$\mathrm{X}_{3}=$ Perlakuan dengan menggunakan pembelajaran Konvensianal.

$\mathrm{T}_{2}=$ Tes akhir (Posttest) disetiap perlakuan sama.

Populasi dari penelitian ini adalah seluruh peserta didik kelas SMP Negeri 1 Teluk Pandan tahun pelajaran 2016. Teknik pengambilan sample yang digunakan adalah cluster random sampling sedangkan sampel yang terpilih adalah kelas VIII-A sebagai kelas eksperimen 1 
(Perlakuan model pembelajaran superitem berbantuan scaffolding), VIII-B sebagai kelas Eksperimen 2 (perlakuan model superitem ) dan kelas VIII-C sebagai kelas control (perlakuan metode ceramah). Teknik pengumpulan data menggunakan model dokumentasi dan model tes. Model dokumentasi digunakan untuk memperoleh kemampuan awal kelas eksperimen 1, eksperimen 2 dan kontrol. Sedangkan model tes digunakan untuk memperoleh data mengenai hasil belajar siswa. Model tes digunakan untuk mengumpulkan data kemampuan pemecahan masalah matematis peserta didik dengan tes berbentuk essay/uraian. Tes diberikan setelah memenuhi validitas soal dan diuji cobakan terlebih dahulu di kelas VIII-A untuk melihat tingkat kesukaran dan daya pembeda butir soal tersebut, serta uji reliabilitas terhadap masing-masing instrumen tes.

Sebelum dilakukan uji hipotesis, terlebih dahulu dilakukan uji prasyarat analisis pada kemampuan awal siswa masing-masing kelas uji keseimbangan dengan taraf signifikansi 0.05. Uji prasyarat analisis yaitu uji normalitas menggunakan uji Lillifors, uji homogenitas dan N-Gain. Jika hasil uji berdistribusi normal dan berasal dari daerah varians yang sama maka dilakukan uji Hipotesis Statistik menggunakan Anava 1 Jalur dengan hipotesis yang digunakan:

1) $\mathrm{H}_{\mathrm{o}}: \mu_{1}=\mu_{2}=\mu_{3}$ (Rata-rata kemampuan pemecahan masalah matematika dengan menggunakan model pembelajaran Superitem berbantuan Scaffolding dengan rata-rata kemampuan pemecahan masalah dengan menggunakan model Superitem serta dengan kemampuan pemecahan masalah dengan menggunakan pendekatan pembelajaran konvensional).

2) $\mathrm{H}_{1}: \mu_{i} \neq \mu_{j}$ (paling sedikit ada dua rataan yang tidak sama)

\section{HASIL DAN PEMBAHASAN}

Setelah data hasil
kemampuan pemecahan maslah
peserta didik terkumpul baik dari
kelas kelas eksperimen 1 (Perlakuan model
superitem berbantuan scaffolding) maupun,
kelas eksperimen 2 (perlakuan model
superitem saja) dan kelas kontrol (Perlakuan
metode konvensional) maka diperoleh:

\section{Tabel 3. Deskripsi Data pretest kemampuan pemecahan masalah matematis peserta didik}

\begin{tabular}{lccccc}
\multicolumn{1}{c}{ Kelompok } & \multicolumn{4}{c}{ Ukuran Tendensi } \\
& $\mathbf{X}_{\max }$ & $\mathbf{X}_{\min }$ & $\bar{c} \begin{array}{c}\text { Sentral } \\
\text { Me }\end{array}$ & $\mathbf{M}_{\mathbf{e}}$ \\
Model Superitem berbantuan & 90 & 45 & 71,50 & 75 & 75 \\
scaffholding (eksperimen 1) & & & & & \\
Model Superitem (eksperimen 2) & 95 & 25 & 60,66 & 70 & 65 \\
Konvensional (kontrol) & 90 & 20 & 54,28 & 60 & 55 \\
\hline
\end{tabular}

Berdasarkan Tabel 1. Hasil kemampuan pemecahan masalah matematis peserta didik pada kelas eksperimen 1 (Perlakuan model superitem berbantuan scaffolding), kelas eksperimen 2 (perlakuan model 
superitem saja) dan kelas kontrol (Perlakuan metode konvensional) dilakukan evaluasi akhir untuk mengetahui hasil pretest peserta didik sebagai pengumpulan data hasil evaluasi akhir diperoleh yang meliputi rata-rata kelas (mean) untuk kelas eksperimen superitem berbantuan scaffholding sebesar 71,50, eksperimen superitem 60,66 dan kelas kontrol sebesar 54,28 sementara untuk nilai tengah kelas eksperimen superitem berbantuan scaffholding yaitu sebesar 75 , eksperimen superitem yaitu sebesar 65 dan kelas kontrol sebesar 55 sedangkan modus pada kelas eksperimen superitem berbantuan scaffholding adalah sebesar 75 , eksperimen superitem adalah 70 dan kelas kontrol sebesar 60 .

Berdasarkan hal ini dapat disimpulkan bahwa hasil kemampuan pemecahan masalah matematis peserta didik kelas eksperimen 1 (Perlakuan model superitem berbantuan scaffolding) tidak sama dengan perlakuan kelas eksperimen 2 (perlakuan model superitem saja) yaitu kemampuan pemecahan masalah matematis peserta didik yang kelas eksperimen 1 (Perlakuan model superitem berbantuan scaffolding) lebih baik dari kelas eksperimen 2 (Perlakuan model superitem saja). Akan tetapi kelas eksperimen 2 (Perlakuan model superitem saja) lebih baik dari kelas kontrol (Perlakuan metode konvensional)

Selanjutnya dilakukan analisis uji asumsi dengan uji normalitas kemampuan pemecahan masalah peserta didik. Hasil uji normalitas dapat dilihat pada Tabel 3. Berikut hasil rekapitulasi perhitungan hasil belajar peserta didik pada kelas eksperimen 1, kelas eksperimen 2 dan kelas kontrol.

\section{Tabel 4. Hasil Perhitungan Uji Normalitas pretest kemampuan pemecahan} masalah matematis peserta didik

\begin{tabular}{lccc}
\multicolumn{1}{c}{ Kelas } & $\boldsymbol{L}_{\text {hitung }}\left(L_{(\alpha, n)}\right)$ & $\boldsymbol{L}_{\text {tabel }}$ & keterangan \\
$\begin{array}{l}\text { Metode superitem berbantuan } \\
\text { scaffolding (eksperimen 1) }\end{array}$ & 0,140 & 0,161 & normal \\
$\begin{array}{l}\text { Model superitem saja } \\
\text { (eksperimen 2) }\end{array}$ & 0,078 & 0,161 & normal \\
Metode konvensional (kontrol) & 0,091 & 0,149 & normal \\
\hline
\end{tabular}

Berdasarkan Tabel 4. hasil uji coba normalitas dengan taraf sigifikansi $\alpha=0,05$ diperoleh kelas eksperimen 1 didapatkan bahwa $L_{\text {hitung }}=0,140$ dan $\quad L_{\text {tabel }}=0,161$ hal ini menunjukan bahwa $L_{\text {hitung }}<$ $L_{\text {tabel }}$ sehingga dapat disimpulkan data berdistribusi normal. kelas eksperimen 2 didapatkan bahwa $L_{\text {hitung }}=0,078$ dan $\quad L_{\text {tabel }}=0,161$ hal ini menunjukan bahwa $L_{\text {hitung }}<$ $L_{\text {tabel }}$ sehingga dapat disimpulkan data berdistribusi normal dan kelas kontrol $L_{\text {hitung }}=0,091$ dan $L_{\text {tabel }}=$ 0,149 hal ini menunjukan bahwa $L_{\text {hitung }}<L_{\text {tabel }}$ sehingga dapat disimpulkan data berdistribusi normal. Berdasarkan hasil uji normalitas dapat disimpulkan bahwa hipotesis nol dari setiap kelompok 
diterima dengan kata lain data yang diperoleh dari setiap kelompok Untuk mengetahui apakah kedua skor memiliki karakter yang sama atau berbeda maka diperlukan uji homogenitas pretest dan post-test. Jika $\chi_{\text {hitung }}^{2} \leq \chi_{\text {tabel }}^{2}\left(\sigma_{1}, \sigma_{2}\right)$ didapat dari distribusi dengan peluang $\frac{1}{2} \alpha$ sedangkan derajat kebebasan $\sigma_{1}\left(n_{1}-\right.$ berasal dari populasi yang berdistribusi normal.

1) dan $\sigma_{2}\left(n_{2}-2\right)$ masing-masing sesuai dengan $d k$ pembilang dan $d k$ penyebut maka data homogen. Hasil pengujian homogenitas dengan taraf signifikan $\alpha=0,05$ dapat dilihat pada Tabel4.

\section{Tabel 5. Hasil uji homogenitas pretest kemampuan berfikir kreatif peserta didik

\begin{tabular}{llcc}
\multicolumn{1}{c}{ Kelas } & $\chi_{\text {hitung }}^{2}$ & $\chi_{\text {tabel }}^{2}$ & keterangan \\
$\begin{array}{l}\text { Metode superitem berbantuan scaffolding } \\
\text { (eksperimen 1) } \\
\begin{array}{l}\text { Model superitem saja (eksperimen 2) } \\
\text { Metode konvensional (kontrol) }\end{array}\end{array}$ & 2,254 & 5,591 & homogen \\
\hline
\end{tabular}

Berdasarkan Tabel 5. Hasil kemampuan pemecahan masalah matematis peserta didik diperoleh $\chi_{\text {hitung }}^{2}=2,254$ dan $\chi_{\text {tabel }}^{2}=5,591$. Menunjukan bahwa $\chi_{\text {hitung }}^{2} \leq$ $\chi_{\text {tabel dengan hal ini dapat }}^{2}$ disimpulkan bahwa $H_{0}$ diterima atau sampel berasal dari populasi yang memiliki varians sama.

Setelah data diketahui berdistribusi normal dan berasal dari variansi yang sama maka selanjutnya dilakukan uji hipostesis (anava 1 jalan sel tak sama). Hasil uji ANOVA yang diperoleh sebagai berikut.

Tabel 6. Hasil Perhitungan Uji anava 1 jalan kemampuan pemacahan masalah matematis

\begin{tabular}{lccc}
\hline \multicolumn{1}{c}{ Kelas } & $F_{\text {hitung }}$ & $F_{\text {tabel }}$ & keterangan \\
$\begin{array}{l}\text { Metode superitem berbantuan scaffolding } \\
\text { (eksperimen 1) }\end{array}$ & & & \\
$\begin{array}{l}\text { Model superitem saja (eksperimen 2) } \\
\text { Metode konvensional (kontrol) }\end{array}$ & 9,137 & 3,44 & $H_{0}$ ditolak \\
\hline
\end{tabular}

Berdasarkan Tabel 6. memperoleh pembelajaran perhitungan diperoleh $\boldsymbol{F}_{\text {hitung }}=$ superitem berbantuan scaffholding 9,137 dan $\boldsymbol{F}_{\text {tabel }}=\mathbf{3}, 44$ sehingga dengan model pembelajaran $\boldsymbol{F}_{\text {hitung }}>\boldsymbol{F}_{\text {tabel }}$, yang berarti $\mathrm{H}_{0}$ superitem tidak sama dengan rataditolak. Dengan demikian, dapat disimpulkan terdapat perbedaan peningkatan kemampuan Pemecahan masalah matematis pada peserta didik dengan kata lain bahwa ratarata kemampuan pemecahan masalah matematis peserta didik yang rata kemampuan pemecahan masalah matematis peserta didik yang memperoleh pembelajaran dengan model pembelajaran konvensional atau dengan kata lain dapat disimpulkan bahwa model pembelajaran superitem berbantuan 
scaffholding menggunakan model pembelajaran superitem dan konvensional memberikan pengaruh yang berbeda terhadap kemampuan pemecahan masalah matematis peserta didik kelas VIII SMP Negeri. Maka selanjutnya dilakukan uji komparasi ganda (uji lanjut) guna mengetahui pengaruh metode mana yang lebih signifikan terhadap kemampuan pemecahan masalah matematis peserta didik. Hasil dari uji komparansi ganda dapat dilihat pada Tabel 6.

Tabel 7. Rekapitulasi Uji Komparasi Ganda

\begin{tabular}{rlcc}
\hline Komparasi & \multicolumn{1}{c}{$\boldsymbol{F}_{\text {hitung }}$} & $\boldsymbol{F}_{\text {tabel }}$ & $\boldsymbol{\alpha}$ \\
$\mu_{1}$ vs $\mu_{2}$ & 6,650 & & \\
$\mu_{1}$ vs $\mu_{3}$ & 18,085 & 6,88 & 0,05 \\
$\mu_{2}$ vs $\mu_{3}$ & 2,417 & & \\
\hline
\end{tabular}

Berdasarkan Tabel 7. dengan membandingkan $\quad F_{\text {hitung }}$ dengan $F_{\text {tabel }}$ rata-rata kemampuan pemecahan masalah matematis peserta didik dapat disimpulkan sebagai berikut:

1. $\mu_{1}$ vs $\mu_{2}$ diperoleh $F_{\text {hitung }}<\mathrm{Ftabel}$ sehingga $\mathrm{H}_{0}$ diterima, maka ratarata kemampuan pemecahan masalah matematis peserta didik tidak ada perbedaan

2. $\mu_{1}$ vs $\mu_{3}$ diperoleh Fhitung $>F_{\text {tabel }}$ sehingga $\mathrm{H}_{0}$ ditolak, maka terdapat perbedaan rata-rata kemampuan pemecahan masalah matematis antara 2 kelompok

3. $\mu_{2} v s \mu_{3}$ dieroleh Fhitung $<$ Ftabel sehingga $\mathrm{H}_{0}$ diterima, maka tidak ada perbedaan rata-rata kemampuan pemecahan masalah matematis peserta didik.

Mengenai ketiga model pembelajaran yang dikenakan pada penelitian ini, diketahui model pembelajaran superitem berbantuan scaffholding dan Model superitem memberikan pengaruh kemampuan pemecahan masalah matematik lebih baik dari pada model pembelajaran konvensional. Hal ini terjadi karena dalam pengerjaan tugas atau diberikan masalah, peserta didik tidak langsung terjun kedalam permasalahan yang kompleks atau sulit yang bisa membuat peserta didik kesulitan dalam mempelajari matematika, melainkan diawali dengan permasalahan yang sangat sederhana. Seperti yang telah dijelaskan oleh (Novianti, 2017) mengungkapkan bahwa agar peserta didik mudah mengerti dan tidak kesulitan dalam pembelajaran matematika, sebaiknya terlebih dahulu diberikan permasalahn yang sederhana atau mudah dicerna peserta didik sehingga peserta didik bisa melangkah sampai hal-hal yang lebih komplek. Selain itu, bantuan scaffholding dalam menerapkan model superitem membuat peserta didik lebih mudah mengerti dan aktif dalam pembelajaran. Terjadainya harapan yang diimpikan kebanyakan pendidik matematika ini karena setiap peserta didik mengalami kesulitan dalam memecahkan masalah maka peserta didik akan dibimbing oleh orang-orang yang lebih mengerti baik dari pendidik maupun dari teman sebaya. Seperti yang telah dijelaskan oleh (Amiruddin, Prastowo, \& Prihandono, 2018) strategi schaffolding sangat memberikan pengaruh terhadap penerapan model pembelajaran, karena strategi ini tidak hanya lebih menekankan membimbing peserta didik yang mengalami kesulitan dalam memecahkan masalah. sehingga peserta 
didik lebih terbantu dalam memecahkan masalah.

Hasil penelitian ini sama dengan hasil penelitian sebelumnya dengan hasil bahwa model pembelajaran superitem berbantuan scaffolding dapat meningkatkan kemampuan pemecahan masalah matematis peserta didik. Seperti yang diungkapkan oleh (Pratiwi et al., 2014) bahwa model pembelajaran superitem berbantuan scaffolding sangat membantu peserta didik dalam meningkatkan kemampuan pemecahan masalah dan hasil belajar matematis peserta didik dalam matematika

\section{SIMPULAN DAN SARAN}

Berdasarkan hasil analisis dan pengolahan data yang telah diuraikan, maka dapat disimpulkan bahwa: terdapat perbedaan kemampuan pemecahan masalah matematis peserta didik yang memperoleh pembelajaran superitem berbantuan scaffholding dengan model pembelajaran superitem tidak sama dengan rata-rata kemampuan pemecahan masalah matematis peserta didik yang memperoleh pembelajaran dengan model pembelajaran konvensional. Selanjutnya kemampuan pemecahan masalah matematis peserta didik dengan model pembelajaran superitem berbantuan scaffholding sama dengan kemampuan pemecahan masalah matematis peserta didik menggunakan model pembelajaran superitem. Kemampuan pemecahan masalah matematis peserta didik dengan model pembelajaran superitem berbantuan scaffholding lebih baik dari pada kemampuan pemecahan masalah matematis peserta didik menggunakan model pembelajaran konvensional. Selanjutnya kemampuan pemecahan masalah matematis peserta didik dengan model pembelajaran superitem sama dengan kemampuan pemecahan masalah matematis peserta didik menggunakan model pembelajaran konvensional.

Berdasarkan kesimpulan penulis menyarankan agar pendidik menggunakan model pembelajaran sueritem berbantuan scaffolding untuk meningkatkan kemampuan pemecahan masalah matematis peserta didik . untuk penelitian selanjutnya direkomendasikan untuk meneliti model ini terhadap kemampuan pemahaman konsep matematis, karena belum pernah dilakukan penelitian sebelumnya.

\section{DAFTAR PUSTAKA}

Amiluddin, R., \& Sugiman, S. (2016). Pengaruh problem posing dan PBL terhadap prestasi belajar, dan motivasi belajar mahasiswa pendidikan matematika. Jurnal Riset Pendidikan Matematika, 3(1), 100-108.

Amiruddin, M., Prastowo, S. B., \& Prihandono, T. (2018). Analisis Pengaruh Strategi Scaffolding Konseptual dalam Model Pembelajaran Terhadap Hasil Belajar Fisika Siswa. FKIP EPROCEEDING, 3(1), 39-45.

ASTIWI, G. O. (2010). Penerapan Model Superitem dengan Optimalisasi Sesi Latihan pada Pembelajaran Materi Faktorisasi 
Desimal, 1 (3), 2018 - 371

Ahmad Kausar Jaya, Sofyan M Soleh, Heny Wulandari

Bentuk Aljabar untuk Meningkatkan Prestasi Belajar Siswa Kelas VIII-I SMPN 10 Mataram Tahun Pelajaran 2010/2011 (PhD Thesis). Universitas Mataram.

Chairani, Z. (2015). Scaffolding dalam pembelajaran matematika. Math Didactic: Jurnal Pendidikan Matematika, 1(1), 39-44.

Dewi, N. K. D. K., Riastini, P. N., \& Pudjawan, K. (2017). Pengaruh Model Pembelajaran Arias Terhadap Pemahaman Konsep Matematika pada Siswa Kelas V SD Negeri 1 Candikusuma. MIMBAR PGSD Undiksha, 5(2).

Novianti, D. E. (2017). Profil Pemecahan Masalah Matematika Dalam Menyelesaikan Permasalahan Pemrograman Linear Ditinjau Dari Kemampuan Komunikasi Matematis Mahasiswa. JIPM (Jurnal Ilmiah Pendidikan Matematika), 6(1), 53-59.

Permatasari, B. I. (2014). Efektivitas Penerapan Model Pembelajaran Superitem dalam Meningkatkan Pemahaman Konsep Matematika Siswa Kelas X SMAN 11 Makassar. MaPan: Jurnal Matematika dan Pembelajaran, 2(1), 136-153. https://doi.org/10.24252/mapa n.2014v2n1a10

Pratiwi, R. Y., Sukestiyarno, S., \& Asikin, M. (2014). Pembentukan Karakter dan Pemecahan Masalah melalui Model Superitem Berbantuan Scaffolding. Unnes Journal of Mathematics Education, 3(1).
Qamar, K., \& Riyadi, S. (2016). Bentuk Scaffolding Dalam Pembelajaran Matematika Menggunakan Aplikasi Berbasis Teks. Prosiding SEMNASDIKMAT.

Rahman Saleh, M. (2016). Efektifitas Strategi Pembelajaran Improve dan Superitem Terhadap Penguasaan Materi Siswa pada Mapel Al-Qur'an Hadits di MA NU Miftahul Falah Cendono Dawe Kudus Tahun Pelajaran 2016/2017. (PhD Thesis). STAIN Kudus.

Sutarmi, N. W., Suharsono, N., \& Warpala, I. W. S. (2013). Pengaruh pembelajaran Scaffolding terhadap Keterampilan Menulis Teks Recount Berbahasa Inggris dan Kreativitas Siswa Kelas VIII SMP Negeri 3 Manggis. Jurnal Teknologi Pembelajaran Indonesia, 3.

Wulandari, P., Mujib, M., \& Putra, F. G. (2016). Pengaruh Model Pembelajaran Investigasi Kelompok berbantuan Perangkat Lunak Maple terhadap Kemampuan Pemecahan Masalah Matematis. Al-Jabar: Jurnal Pendidikan Matematika, 7(1), 101-106.

Yuliana, I., Rokhmat, J., \& Gunada, I. W. (2017). Pengaruh Berpikir Kausalitik Ber-Scaffolding Terhadap Kemampuan Pemecahan-Masalah Kalor pada Siswa SMA. In Prosiding SNFA (Seminar Nasional Fisika dan Aplikasinya) (Vol. 2, pp. 85-92). 